\author{
Konrad Podawca, Ph.D. ${ }^{\text {a)*; }}$ Marek Przywózki, M.Sc. Eng. ${ }^{\text {b) }}$ \\ a) Warsaw University of Life Sciences / Szkoła Główna Gospodarstwa Wiejskiego w Warszawie \\ b) POLFLAM Sp. z o.o. \\ Corresponding author / Autor korespondencyjny: konrad_podawca@sggw.pl
}

\title{
The Impact of Structural and Material Solutions for Glazing Connections on Deformation During Fire
}

\section{Wpływ rozwiązań konstrukcyjno-materiałowych połączeń przeszkleń na odkształcenia podczas dziatania ognia}

\begin{abstract}
Purpose: The article aims to present the differences between different construction and material solutions for glazed partition walls in terms of fire safety as described by the displacements created by flames.

Introduction: Despite the increasingly stringent requirements concerning fire protection and the use of best available techniques, the number of buiIding fires is constantly increasing. Statistics published by the National Headquarters of the State Fire Service show that public buildings account for a significant proportion of these events. In this type of facilities, appropriate design of partition walls is crucial for maintaining the standards of fire safety. Because of an increasing scale of glazed partitions' application in the office buildings' interior arrangement, it is important to note that the fire resistance of the glazings is affected not only by the type or thickness of the fire-resistant glazing but also by the way it is installed, the type of carrying profiles and the sealing materials used.

Methodology: The initial stage included design of an original solution for a frameless glass partition. The partition was subjected to fire tests carried out in accordance with PN-EN 1363-1 and 1364-1 standards. The obtained results of the designed partition were subjected to a comparative analysis with other vertical, framed glazed elements of similar dimensions. The comparative analysis relied on the results provided by the fire tests reports for the glazed partition walls in the framed construction made of wood, aluminium and steel.

Conclusions: The comparative analysis showed that the structure made of steel sections was characterized by the highest susceptibility to displacement caused by fire, in the range of $200 \mathrm{~mm}$. The occurring deformations significantly differed from the results obtained for the other partitions, out of which the lowest deformation values were obtained for the frameless structure (max. $3 \mathrm{~mm}$ ) and wooden profiles (max. $11 \mathrm{~mm}$ ). However, it is worth mentioning that in the case of the wooden structure the deformations were directed towards the outside, and in the other cases, towards the inside of the furnace. The comparative analysis revealed that solutions without a frame, based only on vertical connection of large glazing, provide better results in terms of ensuring fire tightness. This fact may be of considerable importance for the staff evacuation process and fire extinguishing in high-rise office buildings. Keywords: fire, fire resistance, glass partition wall, fire protection glass Type of article: case study
\end{abstract}

Received: 30.06.2019; Reviewed: 03.09.2019; Accepted: 03.09.2019;

Authors' ORCID IDs: K. Podawca - 0000-0001-5261-6657; M. Przywózki - 0000-0003-0155-8930;

Percentage contribution: K. Podawca - 49\%; M. Przywózki - 51\%;

Please cite as: SFT Vol. 53 Issue 1, 2019, pp. 118-128, https://doi.org/10.12845/sft.51.3.2019.7;

This is an open access article under the CC BY-SA 4.0 license (https://creativecommons.org/licenses/by-sa/4.0/)

\section{ABSTRAKT}

Cel: Celem artykułu jest ukazanie różnic pomiędzy różnymi rozwiązaniami konstrukcyjno-materiałowymi przeszklonych ścian działowych w kontekście odporności ogniowej wyznaczanego na podstawie wartości przemieszczeń powstających w nich pod wpływem działania płomieni. Wprowadzenie: Pożary budynków w Polsce to zjawisko przybierające na sile, pomimo coraz bardziej rygorystycznych wymagań ochrony przeciwpożarowej i stosowania nowoczesnych rozwiązań. Analiza szczegółowych statystyk prowadzonych przez Komendę Główną Państwowej Straży Pożarnej pokazuje, że znaczący procent zdarzeń dotyczy budynków użyteczności publicznej. Odpowiednie zaprojektowanie ścian działowych w tego typu obiektach wydaje się być kluczowe dla bezpieczeństwa pożarowego. Ze względu na coraz powszechniejsze stosowanie przegród przeszklonych w projektowaniu przestrzeni obiektów biurowych, warto zwrócić uwagę na fakt, że na odporność ogniową tych witryn ma wpływ nie tylko typ i grubość szkła ogniochronnego, ale również sposób jego mocowania, rodzaj profili nośnych czy użyte materiały izolacyjne i uszczelniające.

Metodologia: Wstępnym etapem było zaprojektowanie autorskiego rozwiązania bezramowej konstrukcji przegrody przeszklonej. Przegrodę tę poddano badaniom ogniowym zgodnie z normami PN-EN 1363-1 i PN-EN 1364-1. Otrzymane rezultaty zaprojektowanej przegrody poddano analizie porównaw- 
czej z innymi pionowymi, ramowymi elementami przeszklonymi o zbliżonych gabarytach. Do porównania przyjęto wyniki zawarte w raportach badań ogniowych przeszklonych ścian działowych w konstrukcji ramowej wykonanej z drewna, aluminium i stali.

Wnioski: Na podstawie analizy porównawczej stwierdzono, że konstrukcję wykonaną z kształtowników stalowych cechowała największa podatność na ugięcie pod wpływem wysokiej temperatury spowodowanej działaniem ognia (wartość rzędu 200 mm). Występujące deformacje znacząco odbiegały od wyników otrzymanych dla pozostałych przegród, z których najmniejsze wartości odkształceń uzyskano dla konstrukcji bezramowej (max. 3 mm) i profili drewnianych (max. $11 \mathrm{~mm}$ ) - z tym, że w konstrukcji drewnianej odkształcenia następowały na zewnątrz, a w pozostałych przypadkach do wnętrza pieca. Wykonana analiza porównawcza pokazała, że rozwiązania pozbawione ram, a bazujące jedynie na łączeniu pionowym dość dużych przeszkleń, dają lepsze wyniki pod względem zapewnienia szczelności i izolacyjności ogniowej. Może to mieć niebagatelne znaczenie podczas procesu ewakuacji ludzi i gaszenia pożaru w wysokich budynkach biurowych.

Słowa kluczowe: pożar, odporność ogniowa, przeszklona ściana działowa, szkło ogniochronne

Typ artykułu: studium przypadku

Przyjęty: 30.06.2019; Zrecenzowany: 03.09.2019; Zatwierdzony: 03.09.2019;

Identyfikatory ORCID autorów: K. Podawca - 0000-0001-5261-6657, M. Przywózki - 0000-0003-0155-8930;

Procentowy wkład merytoryczny: K. Podawca - 49\%; M. Przywózki - 51\%;

Proszę cytować: SFT Vol. 53 Issue 1, 2019, pp. 118-128, https://doi.org/10.12845//sft.53.1.2019.7;

Artykuł udostępniany na licencji CC BY-SA 4.0 (https://creativecommons.org/licenses/by-sa/4.0/)

\section{Introduction}

In spite of stringent fire protection laws and the use of modern solutions, the number of building fires is increasing in Poland (approximately 33000 in 2013 and 2014, nearly 40000 in 2017, and 38000 in 2018). Detailed statistical data gathered by the National Fire Service Headquarters indicates that fires in public utility buildings constitute approximately $7 \%$ of all the fires in buildings and approximately $2 \%$ of all fire events, including forest fires and agricultural land fires [1]. Despite the fact that fires of these types of building structures are uncommon, they pose a significant risk to civilians due to the intended purpose of such buildings. Glass partitioning walls are becoming more common in these types of buildings, and in particular in offices and service buildings. It seems that, because of the benefits they offer, glass partitions are facing no competition. Their popularity is mainly due to the possibility of allowing enough light into the rooms without the need to provide direct window access. Moreover, they are characterised by particularly good acoustic insulation, and allow free arrangement (which is a more convenient solution for employees in comparison to desks arranged in the form of an open space) and different options in terms of joining the elements and combining them with various types of wall structures. Their other advantages include modern design, enabling the possibility of visual contact with other employees or rooms while maintaining the employees' "own" office space and thus providing a certain level of mental comfort during work [2]. The glass partitions are commonly used in tall office buildings which pose a particular challenge for firemen. Therefore, these construction components are particularly important for ensuring fire safety by limiting the spread of fire. The source literature presents examples of studies related to the impact of high temperatures on glass partitions $[3,4,5,6,7,8]$. In many cases, it is demonstrated that the fire resistance of the partitions is affected not only by the type and thickness of fire-resistant glass, but also by the manner of attachment, the type of supporting profiles and the insulation and sealing materials used $[9,10]$.

\section{Wprowadzenie}

Liczba pożarów obiektów budowlanych w Polsce, pomimo rygorystycznych wymagań ochrony przeciwpożarowej i stosowania nowoczesnych rozwiązań, jest coraz wyższa (ok. 33 tys. w 2013 r. i 2014 r., a prawie 40 tys. w 2017 r. i 38 tys. w 2018 r.). Ze szczegółowych statystyk prowadzonych przez Komendę Główną Państwowej Straży Pożarnej wynika, że pożary budynków użyteczności publicznej stanowią ok. 7\% pożarów obiektów budowlanych i ok. $2 \%$ wszystkich zdarzeń o charakterze pożaru, łącznie z pożarami lasów i gruntów rolniczych [1]. Mimo że pożary tego typu budynków nie występują często, ze względu na charakter użytkowania stanowią one duże zagrożenie dla ludzi. W tego rodzaju obiektach - szczególnie biurowych i usługowych - coraz częściej jako ściany działowe stosuje się przegrody przeszklone. Wydaje się, że ze względu na swoje atuty przegrody ze szkła nie mają obecnie konkurencji. 0 ich popularności decyduje możliwość doświetlenia pomieszczeń bez bezpośredniego dostępu do okien, bardzo dobra izolacja akustyczna, swoboda aranżacyjna (wygodniejsze rozwiązanie dla pracowników niż biurka ustawione w przestrzeni open space), a także warianty sposobu łączenia, jak i powiązania ze ścianami o innej konstrukcji. Inne ich zalety to nowoczesny design, możliwość kontaktu wzrokowego z innymi pracownikami czy pomieszczeniami z jednoczesną „własną" przestrzenią biurową, dającą duży komfort psychiczny pracy [2]. Ponieważ przegrody przeszklone są bardzo często stosowane właśnie w wysokich biurowcach, w których gaszenie pożaru jest utrudnione, mają bardzo duże znaczenie w zapewnieniu bezpieczeństwa pożarowego poprzez ograniczenie rozprzestrzeniania się ognia. W literaturze przedmiotu mamy przykłady badań związanych z oddziaływaniem wysokich temperatur na przegrody przeszklone $[3,4,5,6,7,8]$. W wielu przypadkach zwraca się uwagę, że na ich odporność ogniową wpływa nie tylko typ i grubość szkła ogniochronnego, ale również sposób jego mocowania, rodzaj profili nośnych czy użyte materiały izolacyjne i uszczelniające $[9,10]$. 


\section{Aims and methods of analysis}

This article aims to present the differences between the various structural and material solutions for glass partition walls in the context of their fire resistance. Its main objective is to assess the safety of selected glass partitions on the basis of displacements caused by thermal radiation. Although frame displacements do not constitute a standard parameter [11] and they do not directly affect the evaluation of the element's performance as a fire barrier with a specific resistance, their registration is required [12]. The aforementioned parameters are of great importance for ensuring fire tightness defined as the ability of a given vertical glazed partition to withstand fire on one side, without transferring it to the non-heated side as a result of penetration of flames or hot gases [13]. In addition, one of the three components of fire tightness assessment include the formation of cracks or holes exceeding the permissible dimensions [13] - this type of damage may be caused by frame deflection. At the same time, the displacement values are taken into account to increase the dimensions of the structure in relation to the size of the tested component.

The initial stage involved the development of an original design for a frameless glass partition. That partition was subjected to fire tests [14] carried out in the research laboratory at Certbud Sp. z o.o. The tests were performed in a brick test furnace made of refractory bricks, covered with a $5 \mathrm{~cm}$ layer of ceramic material on the inside. The layer served as thermal insulation and protected the interior walls of the furnace against damage. The tested component was built in as the front wall. The test conditions, i.e. temperature increase, pressure and atmosphere of the furnace, as well as ambient temperature, were all set in accordance with the requirements of item 5 of the PN-EN 1363-1 standard [15]. All displacements were recorded in similar time intervals using one of two measurement methods. The first method consisted of stretching a red wire across the entire width of the partition and measuring the distance to the surface of the test piece for each of the selected points. The difference between the obtained measurements during the test represented the size of the displacement of the test piece. The second method was based on the use of a laser rangefinder, which recorded the changing deflection over time. The procedures remained compliant with the PN-EN 1363-1, PN-EN 1364-1 standards concerning fire resistance tests for non-load bearing elements $[12,15]$.

The obtained deflection test results for each partition were compared with other vertical glass elements of similar dimensions. The summary of the test results also included the results of fire test reports of glass partition walls framed in wood, aluminium and steel constructions, as retrieved from Polflam archives [16].

The presented analysis should be regarded as a case study, since it is based solely on the analysis of events (fire tests of select four glazed partitions). The criteria for their selection included: similar dimensions, diverse materials of partition wall frames, diverse solutions for joining glass panels and various glass thickness.

\section{Cel i metody analizy}

Celem artykułu było ukazanie różnic pomiędzy rozwiązaniami konstrukcyjno-materiałowymi przeszklonych ścian działowych w kontekście ich odporności ogniowej. Za główny cel obrano ocenę bezpieczeństwa wybranych przegród przeszklonych na podstawie wartości ugięć powstających pod wpływem działania promieniowania cieplnego. Pomimo że odkształcenia ram nie stanowią normowego parametru [11] i nie mają bezpośredniego wpływu na ocenę skuteczności funkcjonowania elementu jako bariery o określonej odporności ogniowej, to ich rejestracja jest wymagana [12]. Uznano, że powyższe parametry mają duże znaczenie przy zachowaniu szczelności ogniowej, rozumianej jako zdolność danej pionowej przegrody przeszklonej do wytrzymania oddziaływania ognia z jednej strony, bez przeniesienia go na stronę nienagrzewaną w wyniku przeniknięcia płomieni lub gorących gazów [13]. Dodatkowo jednym z trzech aspektów oceny szczelności ogniowej jest wystąpienie pęknięć lub otworów przekraczających dopuszczalne wymiary [13] - ugięcia ram mogą być powodem powstania takich uszkodzeń. Jednocześnie wartości deformacji są parametrem rozpatrywanym w kontekście zwiększenia wymiarów konstrukcji w stosunku do wielkości badanego elementu.

Wstępnym etapem było zaprojektowanie autorskiego rozwiązania bezramowej konstrukcji przegrody przeszklonej. Przegrodę tę poddano badaniom ogniowym [14], które przeprowadzono w laboratorium badawczym Certbud Sp. z o.o. Badanie wykonano w piecu badawczym, murowanym z cegieł szamotowych obłożonych od wnętrza ok. pięciocentymetrową warstwą materiału ceramicznego, który jest termicznym izolatorem oraz osłoną przed uszkodzeniami wewnętrznych ścian pieca. Przednią ścianę stanowił wbudowany element próbny. Warunki wykonania badania tj. przyrost temperatury, ciśnienie i atmosfera pieca oraz temperatura otoczenia były zgodne z wymogami punktu 5 normy PN-EN 1363-1 [15]. Ugięcia zostały zarejestrowane i zapisywane w zbliżonych przedziałach czasowych z zastosowaniem jednej z dwóch metod pomiaru. Pierwsza z nich polegała na rozpięciu żyłki na całej szerokości przegrody i zmierzeniu odległości do powierzchni elementu próbnego dla każdego z wytypowanych punktów. Różnica wynikająca z pozyskanych pomiarów w trakcie badania stanowiła informację o wielkości deformacji elementu próbnego. Druga metoda opierała się na zastosowaniu dalmierza laserowego, który rejestrował zmieniające się ugięcie w czasie. Procedury były zgodne z normami PN-EN 1363-1, PN-EN 1364-1 dotyczącymi badań odporności ogniowej elementów nienośnych $[12,15]$.

Otrzymane wyniki ugięć danej przegrody porównano z wynikami innych pionowych, ramowych elementów przeszklonych o zbliżonych gabarytach. Do zestawienia przyjęto dane zawarte $w$ raportach badań ogniowych przeszklonych ścian działowych w konstrukcji ramowej wykonanej z drewna, aluminium i stali, zaczerpnięte $z$ archiwalnych zasobów Polflamu [16].

Przedstawioną analizę należy uznać za studium przypadku, ponieważ bazuje na analizie zdarzeń (były nimi badania ogniowe wybranych czterech przegród przeszklonych). Kryteriami ich wyboru były: zbliżone wymiary, zróżnicowany materiał ram przegrody, zróżnicowane rozwiązania łączenia tafli szkła oraz grubość szkła. 


\section{Characteristics of analysed items}

\section{Glass partition walls without profiles (Structure 1)}

The designed glass wall was made of $30 \mathrm{~mm}$ thick glass, consisting of two layers of tempered glass with a thickness of $10 \mathrm{~mm}$ separated by a $10 \mathrm{~mm}$ layer of flame-retardant gel. This thickness resulted from the necessity to maintain the required stability of the partition with the lack of profiles connecting the adjacent glasses. The locking element on the partition wall was manufactured using special clamps made of thin steel sheet. The clamps were placed in specific points, fixed to the surface using mounting anchors. The bending of the clamps on both sides of the glass provides appropriate stability. The use of a $2 \times 20 \mathrm{~mm}$ intumescent seal ensures adequate tightness around the perimeter of the glass. The gaps between the edge of the opening and the glass have been closed with flame-retardant silicone on both sides of the opening. The proposed design also includes two fireproof plasterboard strips with a total thickness of $25 \mathrm{~mm}$. This allows the glass to be attached symmetrically and provides additional protection for the panel fixing points (fig. 1a).

\section{Charakterystyka analizowanych obiektów}

\section{Przegroda przeszklona bezprofilowa (Obiekt 1)}

W zaprojektowanej przeszklonej ścianie zaproponowano zastosowanie szkła o grubości $30 \mathrm{~mm}$, złożonego z dwóch warstw szkła hartowanego o grubości $10 \mathrm{~mm}$ oraz $10 \mathrm{~mm}$ warstwy żelu ogniochronnego pomiędzy nimi. Grubość ta wynikała z konieczności zachowania wymaganej stateczności przegrody przy jednoczesnym braku profili łączących sąsiednie przeszklenia. Mocowanie na obwodzie przegrody wykonano z zastosowaniem specjalnych zacisków wykonanych z cienkiej stalowej blachy. Zostały one umieszczone punktowo i zamocowane do podłoża w sposób trwały z wykorzystaniem kołków mocujących. Zagięcie wydzielonych części zacisków na obie strony szyb pozwala na ich ustabilizowanie. Użycie uszczelki pęczniejącej o przekroju $2 \times 20 \mathrm{~mm}$ ma zapewnić szczelność na obwodzie układu szyb. Powstałe szczeliny pomiędzy krawędzią otworu a szkłem zostały zamknięte silikonem ogniochronnym po obu jego stronach. W proponowanym układzie występują również po dwa paski ognioodpornej płyty gipsowo-kartonowej o łącznej grubości $25 \mathrm{~mm}$. Pozwala to na symetryczne mocowanie szkła oraz dodatkową osłonę miejsca mocowania tafli (ryc. 1a).

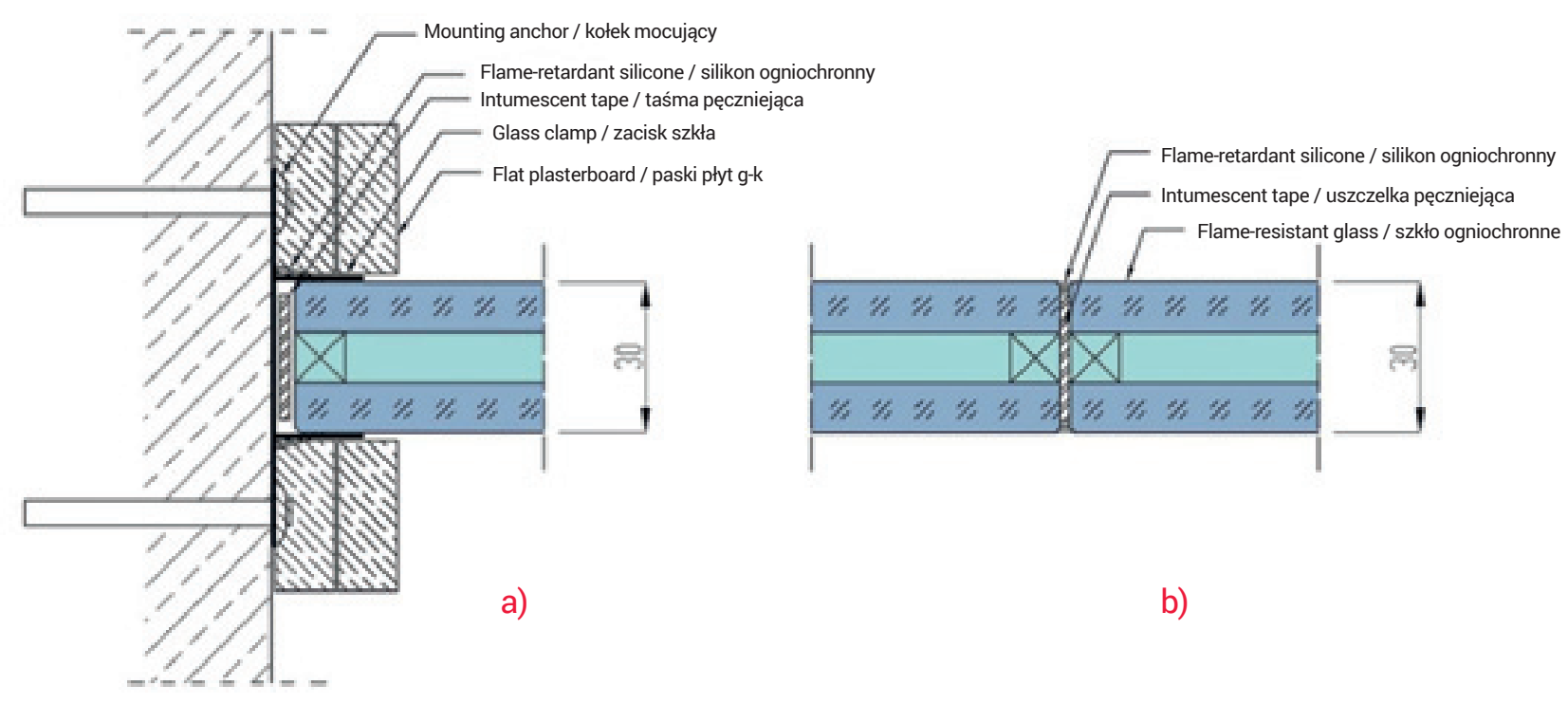

Figure 1. Cross-section of external (a) and internal (b) frameless construction connections

Rycina 1. Przekrój połączeń konstrukcji bezramowej a) zewnętrznego b) środkowego

Source: Own elaboration based on technical data.

Źródło: Opracowanie własne na podstawie danych technicznych.

Only vertical connections were present between the adjacent glass panes. Their tightness - similarly as in the case of side fixing - was ensured using intumescent tape, and the gap at the glass joint was filled with flame retardant silicone (fig. 1b).

\section{Glass partition with wooden frames (Structure 2)}

The profiles of the partition were manufactured using glued laminated wood with a density of $550 \mathrm{~kg} / \mathrm{m}^{3}$, additionally pressure-impregnated with a salt-based water agent. The $20 \mathrm{~mm}$-thick
Między sąsiednimi taflami szkła występowały jedynie połączenia pionowe. Ich szczelność - podobnie jak w przypadku mocowania bocznego - zapewniona została dzięki umieszczeniu taśmy pęczniejącej, a zamknięcie powstałej szczeliny na styku szyb wykonane zostało przy użyciu silikonu ogniochronnego (ryc. 1b).

\section{Przegroda przeszklona z ramami drewnianymi (Obiekt 2)}

Profile zostały wykonane $z$ drewna klejonego o gęstości $550 \mathrm{~kg} / \mathrm{m}^{3}$, dodatkowo zaimpregnowanego ciśnieniowo prepa- 
fire-resistant partition glass is made of two layers of $5 \mathrm{~mm}$ toughened glass with $10 \mathrm{~mm}$ thick flame-retardant gel placed between the layers. The construction is placed inside a structure made of 68 $\mathrm{mm}$ scantling timber. A wooden profile (glass clip) was used for fixing. It was located along the sides of each glazing and attached to the main frame with screws, which provided a durable and stable fixing for the glass. In each case, the glass panel was protected with a $2 \times 20 \mathrm{~mm}$ intumescent tape, while the side edges of the pane were insulated with a strip of additional ceramic material located at the wood joints, additionally protected with a layer of flame-retardant silicone (fig. 2a). The adjacent glass panes were joined using two identical wooden profiles, while a plasterboard insert was placed at the joint (fig. 2b). ratem wodnym na bazie soli. Szyby ogniochronne o grubości $20 \mathrm{~mm}$ zbudowane $\mathrm{z}$ dwóch warstw szkła hartowanego o grubości $5 \mathrm{~mm}$ oraz $10 \mathrm{~mm}$ warstwy żelu ogniochronnego między nimi, utrzymywano w konstrukcji wykonanej z kantówek o szerokości $68 \mathrm{~mm}$. Do mocowania zastosowano drewniany profil (tzw. klips szklący). Był on zlokalizowany wzdłuż boków każdego przeszklenia i przytwierdzony do głównej ramy przy pomocy wkrętów, co zapewniało trwałe i stabilne mocowanie przeszkleń. W każdym przypadku czoło szyby zabezpieczono taśmą pęczniejącą o przekroju $2 \times 20 \mathrm{~mm}$, natomiast krawędzie boczne szyb, na styku z ramą drewnianą, wyizolowano przy pomocy paska dodatkowego materiału ceramicznego, którego zabezpieczenie stanowiła warstwa silikonu ogniochronnego (ryc. 2a). Łączenie sąsiednich tafli szkła wykonano przy zastosowaniu dwóch identycznych profili drewnianych, a w miejscu ich styku zastosowano wkładkę wykonaną z płyty gipsowej (ryc. 2b).
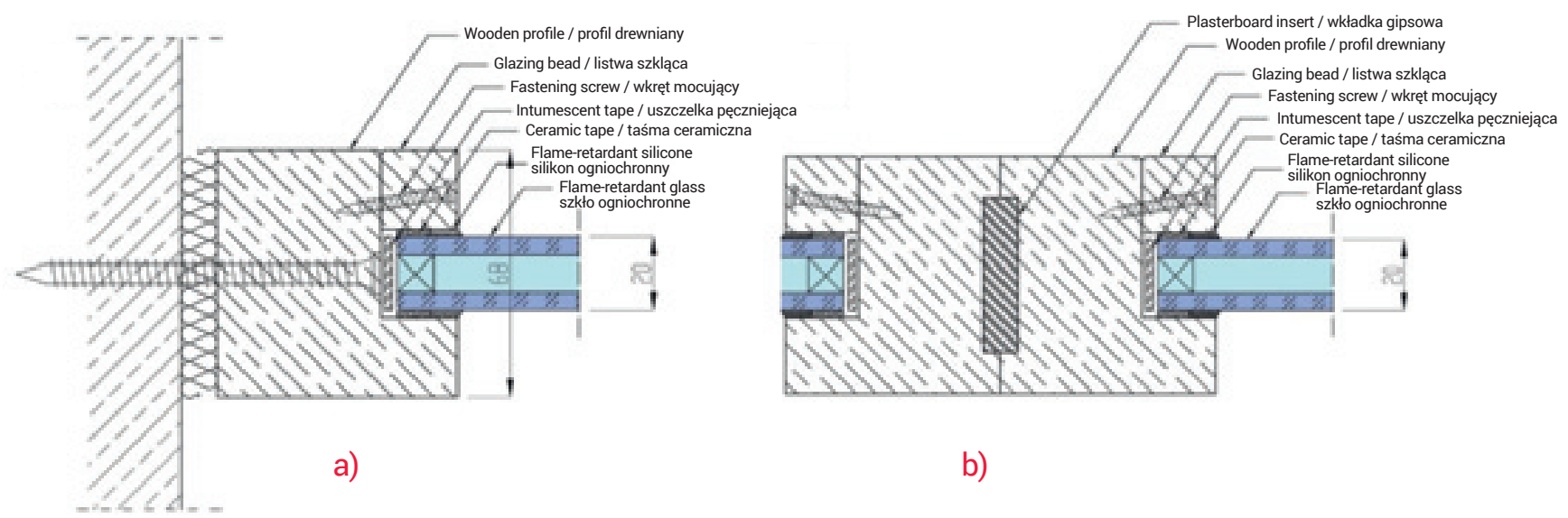

Figure 2. Cross-section of external (a) and internal (b) wooden construction connections

Rycina 2. Przekrój połączeń konstrukcji drewnianej a) zewnętrznego b) środkowego

Source: Own elaboration based on technical data

Źródło: Opracowanie własne na podstawie danych technicznych.

\section{Glazed partition with aluminium frames (Structure 3)}

Aluminium profiles were joined together by connectors or by bending appropriate elements to create a frame. The window was divided into several glazing units, and the largest had a size of $1500 \times 3000 \mathrm{~mm}$. The main, $78 \mathrm{~mm}$-thick, profiles consisted of two sections connected by a spacer made of reinforced plastic. The profile had a symmetric design which allowed axial fixation of the $20 \mathrm{~mm}$-thick fire-resistant glass similar in design to Structure 2. The internal chamber was filled with plasterboard strips to limit the penetration of temperature to the non-heated side (fig. 3a).

The partition glass was kept inside the frames by steel brackets installed at certain points along the edges. An active $2 \times 20 \mathrm{~mm}$ seal expanding under heat was placed in the profiles along the outer edge of the glass. and on the profiles running around the perimeter of the glass, an active $2 \times 20 \mathrm{~mm}$ gasket was used, which increases in volume when exposed to heat (fig. 3b).

\section{Przegroda przeszklona z ramami aluminiowymi (Obiekt 3)}

Profile aluminiowe zespolono za pomocą łączników lub poprzez zagniatanie odpowiednich elementów, tworząc ramę. Witryna była dzielona na kilka przeszkleń, z których największe miało wymiary $1500 \times 3000 \mathrm{~mm}$. Główne profile o grubości $78 \mathrm{~mm}$ składały się z dwóch kształtowników połączonych za pomocą tzw. przekładki wykonanej ze zbrojonego tworzywa sztucznego. Taki profil charakteryzował się symetryczną budową i pozwalał na osiowe zamocowanie szkła ogniochronnego o grubości $20 \mathrm{~mm}$ i budowie jak w obiekcie 2. Środkową komorę wypełniono paskami płyty gipsowo-kartonowej dla ograniczenia przenikania wysokich temperatur na stronę nienagrzewaną (ryc. 3a).

Przeszklenia utrzymywano $w$ ramach za pomocą stalowych kątowników umieszczonych punktowo wzdłuż krawędzi, a na profilach biegnących po obwodzie szyb zastosowano aktywną uszczelkę o przekroju $2 \times 20$ mm, która zwiększa swoją objętość podczas działania wysokiej temperatury (ryc. 3b). 

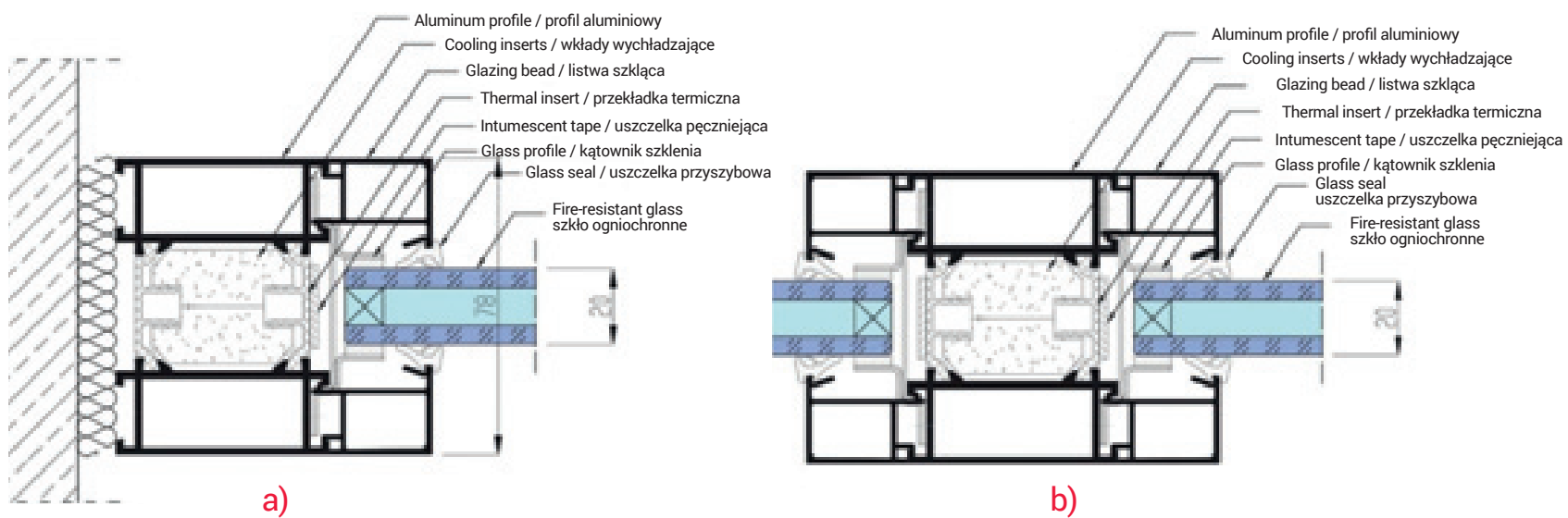

b)

Figure 3. Cross-section of external (a) and internal (b) aluminum construction connections

Rycina 3. Przekrój połączeń konstrukcji aluminiowej a) zewnętrznego b) środkowego

Źródło: Opracowanie własne na podstawie danych technicznych.

Source: Own elaboration based on technical data.

\section{Glazed partition with steel frames (Structure 4)}

The last partition (structure 4) had steel profiles manufactured from bent $\mathrm{C}$-shaped steel sheets connected by thermal inserts. Mechanically folded sheet metal elements were used to join all the components together, creating a $60 \mathrm{~mm}$-thick profile. The two chambers created in that manner were filled with fire-resistant plasterboards to reduce the temperature on the non-heated side. Single-sided steel glazing beads were used to attach the $20 \mathrm{~mm}$ glass (design as per structure 2) in the frame (the largest with the size of $1500 \times 300 \mathrm{~mm}$ ), located on the perimeter gaps. The edges on the other side were held in place on an adequately formed main profile. Ceramic tapes were used at the steel element joints. The tightness between the glass and the steel construction was secured with a $2 \times 15 \mathrm{~mm}$ intumescent tape. Adjacent glass panels were connected using profiles with a design similar to the side profile (fig. 4).

\section{Przegroda przeszklona z ramami stalowymi (Obiekt 4)}

W ostatniej przeszklonej witrynie profile stalowe (obiekt 4) wykonano z odpowiednio wygiętej stalowej blachy o przekroju w kształcie litery C. Połączono je poprzez zastosowanie przekładki termicznej. Maszynowe zagniatanie krawędzi blachy spoiło elementy w całość, tworząc kształtownik o grubości $60 \mathrm{~mm}$. W powstałych w ten sposób dwóch komorach umieszczono wkłady wykonane z ognioodpornych płyt gipsowo-kartonowych mających za zadanie zmniejszenie wzrostu temperatury na stronie nienagrzewanej. Do zamocowania szyb (o grubości $20 \mathrm{~mm}$ i budowie jak w obiekcie 2) w ramie (największa o wymiarze $1500 \times 3000 \mathrm{~mm}$ ) wykorzystano jednostronne stalowe listwy szklące, które biegły po obwodzie otworów. Ich krawędzie $z$ drugiej strony opierały się na przyldze wytworzonej z odpowiednio uformowanego głównego profilu. W miejscu styku stalowych elementów z obiema powierzchniami szkła użyto taśm ceramicznych, a w celu zapewnienia szczelności połączenia szyb z konstrukcją stalową zastosowano uszczelkę pęczniejącą o przekroju $2 \times 15 \mathrm{~mm}$. Połączenie sąsiednich przeszkleń zapewniono przez zastosowanie profili o budowie podobnej do profilu bocznego (ryc. 4).

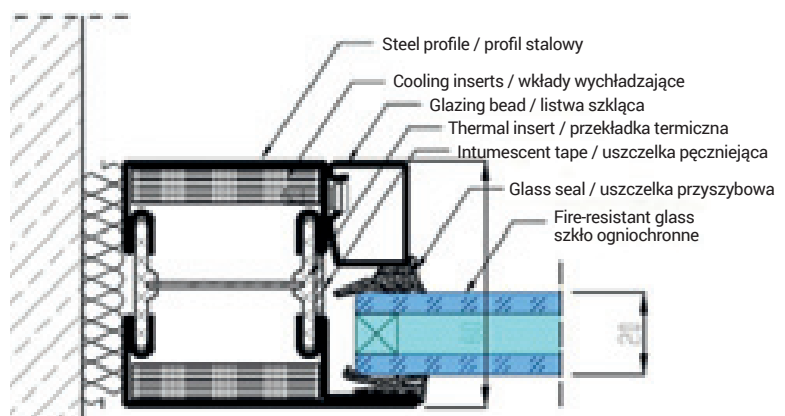

a)

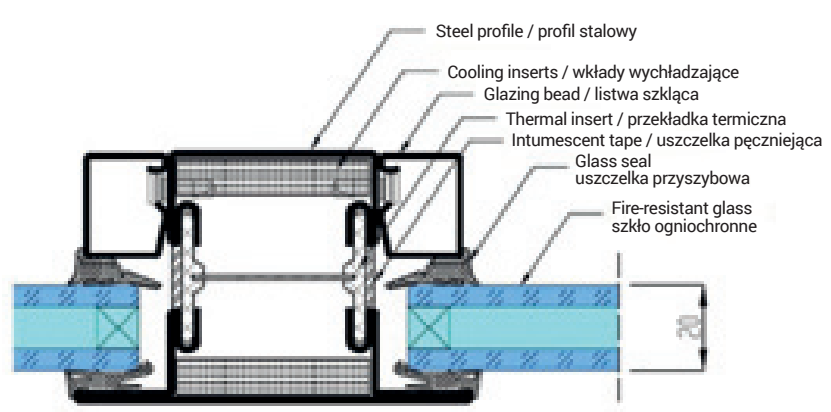

b)

Figure 4. Cross-section of external (a) and internal (b) steel construction connections Rycina 4. Przekrój połączeń konstrukcji stalowej a) zewnętrznego b) środkowego

Source: Own elaboration based on technical data.

Źródło: Opracowanie własne na podstawie danych technicznych. 


\section{Results}

Displacements of frames and glass partitions are presented in table 1. The displacements were measured at four specific points (points $A-D$ ). These points were selected in accordance with the PN-EN-1364-1 standard [12]. They are of particular importance for maintaining fire-thigthness qualities during fire hazard. Figure 5 shows the location of the measurement points for each structural solution.

\section{Wyniki}

Odkształcenia ram i połączeń przeszkleń zostały zaprezentowane w tabeli 1. Pomiary odkształceń wykonano w czterech charakterystycznych miejscach (punkty A-D). Zostały one wytypowane zgodnie z zapisami normy PN-EN-1364-1 [12]. Są to punkty, które mają bardzo duże znaczenie w utrzymaniu szczelności ogniowej podczas pożaru. W zależności od rozwiązań konstrukcyjnych lokalizację miejsc pomiarowych ukazuje rycina 5 .
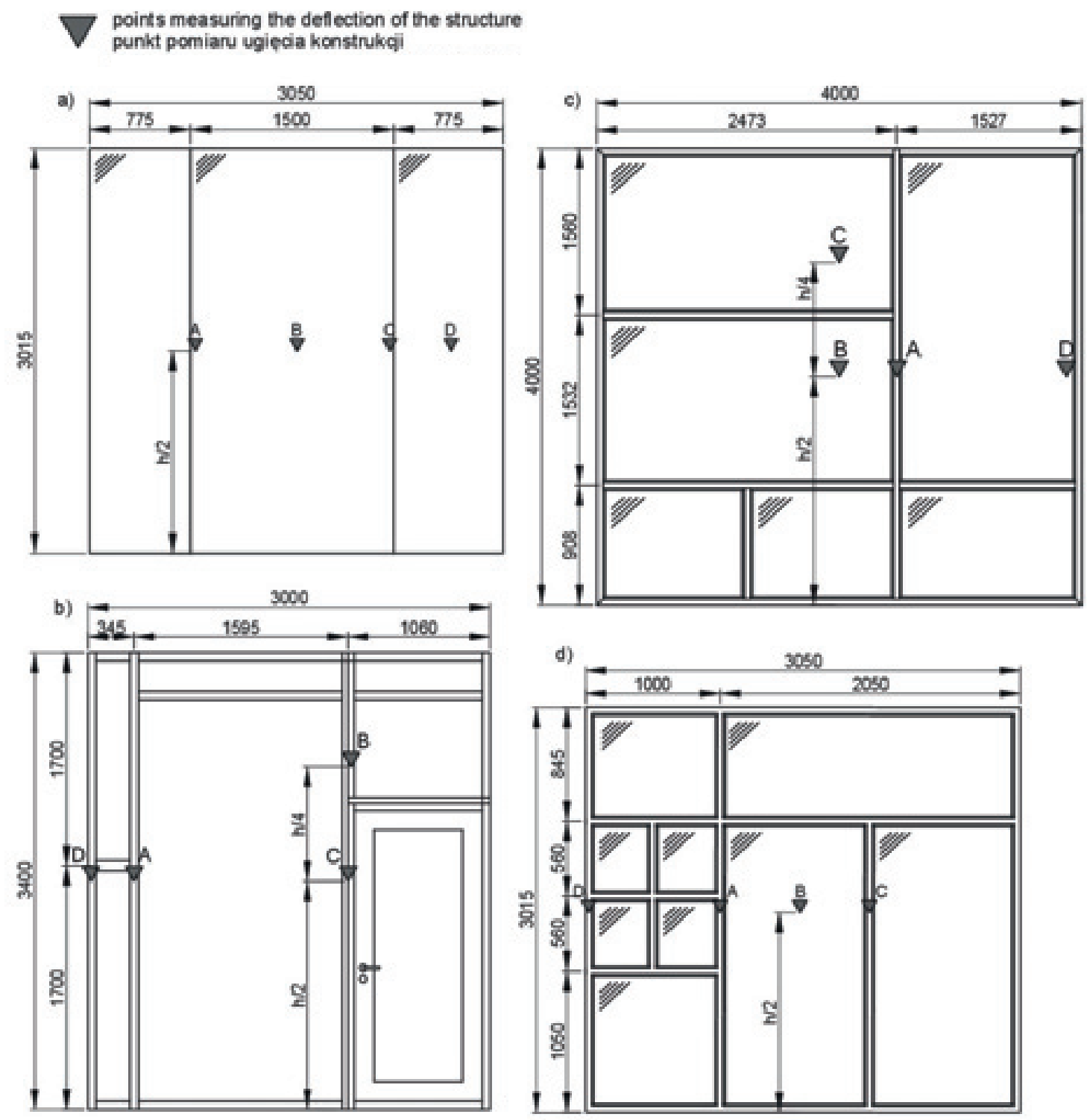

Figure 5. Scheme of glazed partitions and the distribution of measurement points in accordance with table 1 a) structure 1 , b) structure 2 , c) structure 3, d) structure 4

Rycina 5. Schemat przeszklonych przegród oraz rozmieszczenie punktów pomiarów zgodnie z tabelą 1, a) obiekt 1, b) obiekt 2, c) obiekt 3, d) obiekt 4

Source: Own elaboration.

Źródło: Opracowanie własne. 
Table 1. Displacement values in the analyzed glass partitions

Tabela 1. Wartości przemieszczeń w analizowanych przegrodach przeszklonych

\begin{tabular}{|c|c|c|c|c|c|c|c|c|c|c|c|c|c|c|c|c|}
\hline \multirow{4}{*}{$\begin{array}{l}\text { Time / Czas } \\
\text { [min] }\end{array}$} & \multicolumn{16}{|c|}{ Structure number / Numer obiektu } \\
\hline & \multicolumn{4}{|c|}{1} & \multicolumn{3}{|c|}{2} & & \multicolumn{4}{|c|}{3} & \multicolumn{4}{|c|}{4} \\
\hline & \multicolumn{16}{|c|}{ Displacement in measurement locations according to fig. 5 [mm] / Przemieszczenie w miejscach pomiaru zgodnie z ryc. 5} \\
\hline & A & B & C & D & A & B & C & D & A & B & C & D & A & B & C & D \\
\hline 0 & 0 & 0 & 0 & 0 & 0 & 0 & 0 & 0 & 0 & 0 & 0 & 0 & 0 & 0 & 0 & 0 \\
\hline 10 & $-1^{*}$ & 1 & 0 & 2 & -1 & -2 & 1 & -2 & 25 & 29 & 29 & 50 & 174 & 184 & 186 & 32 \\
\hline 20 & 0 & 2 & 2 & 3 & -2 & -4 & -2 & -2 & 17 & 18 & 16 & 49 & 195 & 190 & 180 & 92 \\
\hline 25 & 1 & 2 & 3 & 3 & -4 & -6 & -4 & -3 & 8 & 12 & 11 & 48 & 200 & 189 & 176 & 89 \\
\hline 30 & 1 & 2 & 3 & 3 & -5 & -11 & -8 & -3 & 7 & 13 & 11 & 47 & 204 & 191 & 175 & 90 \\
\hline
\end{tabular}

Źródło: Opracowanie własne na podstawie wyników badań.

Source: Own elaboration based on test results.

* positive values represent the displacement towards the inside of the furnace, negative values represent the displacements in the outer direction

* wartości dodatnie określają deformację do wnętrza komory pieca, natomiast ujemne w kierunku zewnętrznym

The glass partition with wooden profiles was characterized by a slight initial displacement of up to $3 \mathrm{~mm}$. Over time, the displacement increased steadily in the outer direction until it reached a maximum value of $11 \mathrm{~mm}$. The parameters taken at measuring point were similar with a tolerance of $\pm 4 \mathrm{~mm}$ (fig. 6a). The partition made of aluminium profiles was significantly deformed towards the interior of the furnace during the first 10 minutes of the test. The maximum value of $50 \mathrm{~mm}$ has been measured at a point close to the unrestrained edge. It differs from the other results, as the profile is not rigidly fixed to the test frame, allowing it to move freely. By the end of the test, the structure reduced its displacement to approximately $10 \mathrm{~mm}$ at its central section (fig. 6b).
Witryna o profilach drewnianych charakteryzowała się niewielkim ugięciem początkowym sięgającym $3 \mathrm{~mm}$. Wraz z upływem czasu ugięcie systematycznie powiększało się w kierunku zewnętrznym, by osiągnąć maksymalną wartość $11 \mathrm{~mm}$. Odczytywane parametry dla każdego miejsca pomiarowego były zbliżone z uwzględnieniem tolerancji $₫ 4 \mathrm{~mm}$ (ryc. 6a). Przegroda zbudowana $z$ profili aluminiowych uległa znacznemu odkształceniu w kierunku do wnętrza pieca w pierwszych 10 minutach badania. Maksymalna wartość $50 \mathrm{~mm}$ została zmierzona w punkcie zlokalizowanym w niewielkiej odległości od krawędzi wolnej. Różni się ona od pozostałych wyników z uwagi na brak sztywnego mocowania profilu do ramy badawczej, co umożliwia jego swobodny ruch. Wraz ze zbliżaniem się do końca przewidzianego czasu trwania testu konstrukcja zmniejszała swoje odkształcenie, osiągając ok. $10 \mathrm{~mm}$ dla punktów zlokalizowanych w jej środkowej części (ryc. 6b).

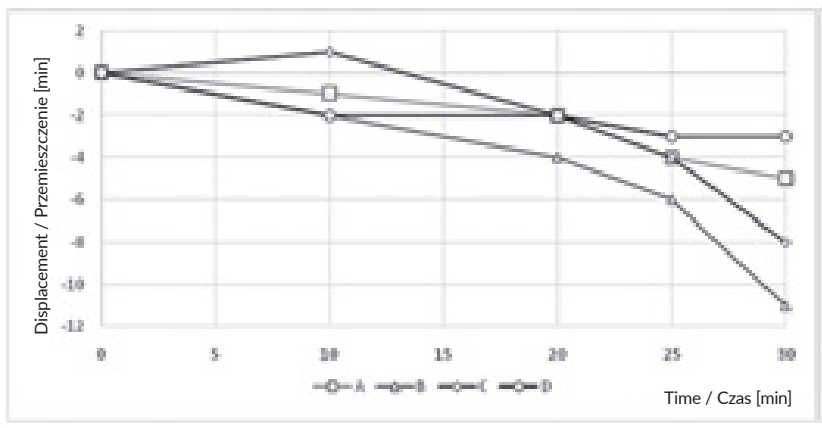

a)

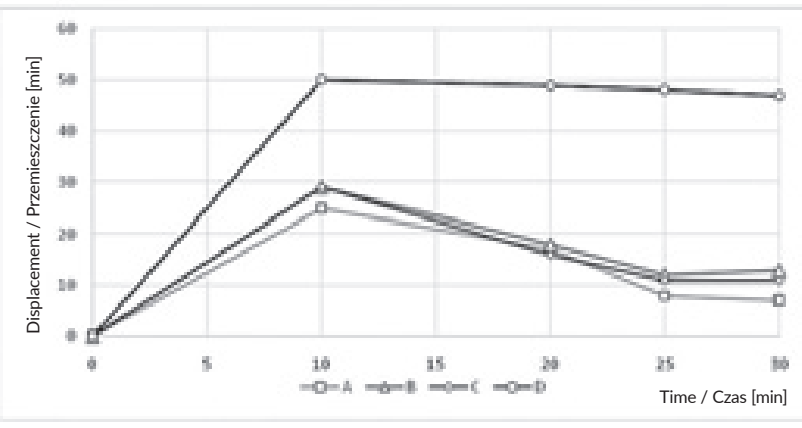

b)

Figure 6. Changes of displacements at points $A-D$ in structures 2 and 3

Rycina 6. Zmiany przemieszczeń w punktach A-D w obiektach 2 i 3

Source: Own elaboration based on test results.

Źródło: Opracowanie własne na podstawie wyników badań. 
The partition with steel profiles was significantly deformed towards the interior of the chamber at the initial stage of the test. After 10 minutes, the points located at the centre of the partition reached the highest values, exceeding $180 \mathrm{~mm}$. The result was maintained at the same level until the end of the test, with a tolerance of $\pm 10 \mathrm{~mm}$. The results taken at measuring point A of the steel partition differed significantly in relation to the other partitions. This difference can be attributed to its location on the profile located at the unrestrained edge. That component of the structure can move freely due to the use of mineral wood with a thickness of $50 \mathrm{~mm}$, which also seals the construction during displacement. The profile in contact with wool was partially cooled by the wool, and the steel crossbars connected with it increased its rigidity. Both factors helped reduce the displacements occurring in this part of the glass partition in relation to the remaining parts of its surface (fig. 7a). In the partition with a frameless system for fixing glass, where the measurement points were located only on the surface of the glass, the displacements occurring in the initial stage of the test did not exceed $2 \mathrm{~mm}$ towards the inside of the furnace. Over time, the displacements increased slightly by $1 \mathrm{~mm}$. The highest observed value of $3 \mathrm{~mm}$ was measured at a point located close to the unrestrained edge (fig. 7b).
Witryna o profilach stalowych charakteryzowała się dużym wzrostem ugięcia w początkowym czasie badania w kierunku do ognia. Po upływie 10 minut wartości z punktów umieszczonych w środkowej części przegrody osiągnęły najwyższe wskazania, przekraczając $180 \mathrm{~mm}$. Wynik utrzymywał się do końca testu na równym poziomie z tolerancją $\pm 10 \mathrm{~mm}$. Odczyty dla punktu pomiarowego A przegrody stalowej były odmienne od pozostałych. Różnica wynikała z jego umiejscowienia na profilu stanowiącym krawędź wolną. Swoboda ruchu tej części konstrukcji zapewniono poprzez zastosowanie wełny mineralnej o grubości $50 \mathrm{~mm}$, która gwarantowała zachowanie szczelności podczas deformacji. Profil stykający się z wełną był częściowo przez nią wychładzany, a łączące się z nim stalowe poprzeczki zwiększały jego sztywność. Oba czynniki pozwoliły na zredukowanie zniekształceń występujących w tej części witryny w porównaniu do pozostałej jej powierzchni (ryc. 7a). W zaprojektowanej witrynie z bezramowym mocowaniem przeszkleń, w której punkty pomiarowe rozmieszczone zostały jedynie na powierzchni szkła, ugięcia występujące w początkowej fazie badania nie przekraczały $2 \mathrm{~mm}$ w kierunku do wnętrza pieca. Wraz z upływem czasu zaobserwowano nieznaczny wzrost deformacji sięgający ok. $1 \mathrm{~mm}$. Największą zaobserwowaną wartość $3 \mathrm{~mm}$ odczytano z punktu zlokalizowanego w bliskiej odległości od krawędzi wolnej (ryc. 7b).

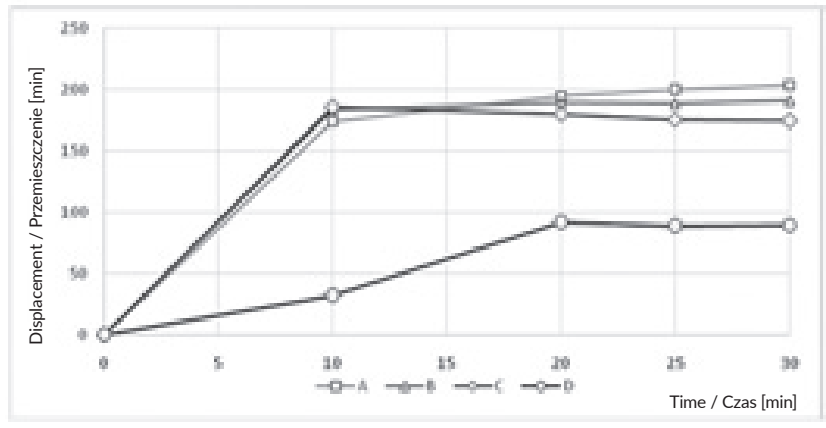

a)

Figure 7. Changes of displacements at points $A-D$ in structures 4 and 1 Rycina 7. Zmiany przemieszczeń w punktach A-D w obiektach 4 i 1 Source: Own elaboration based on test results.

Źródło: Opracowanie własne na podstawie wyników badań.

\section{Conclusions and summary}

Based on comparative analysis, it was established that a structure made of steel sections was the most susceptible to displacement in high temperatures caused by fire. The displacements significantly differed from the results obtained for other partitions. The smallest displacements during fire tests were observed in the case of the frameless partition and the partition with wooden profiles (fig. 8).

It must be noted that all of the tested partitions have met relevant fire resistance requirements, reaching class $\mathrm{El} 30$ in 30 minutes.

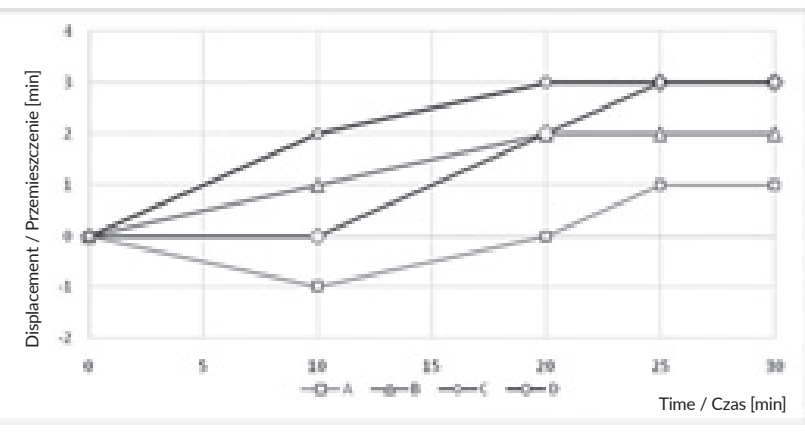

b)

\section{Wnioski i podsumowanie}

Na podstawie analizy porównawczej stwierdzono, że konstrukcja wykonana z kształtowników stalowych cechowała się największą podatnością na ugięcie pod wpływem wysokiej temperatury spowodowanej działaniem ognia. Występujące deformacje znacząco odbiegały od wyników otrzymanych dla pozostałych przegród. Najmniejsze ugięcia w trakcie badań ogniowych zaobserwowano dla przegrody bezramowej oraz przegrody zbudowanej z profili drewnianych (ryc. 8).

Należy zaznaczyć, że wszystkie badane konstrukcje spełniły stawiane wymagania odporności ogniowej, w czasie $30 \mathrm{~min}$, osiągając klasę El 30. 
The analysis unequivocally showed that material and structural solutions used for manufacturing the profiles connecting protective glass have a significant impact on fire tightness. The types of connections which are subject to minor displacements impact on the stability of the partition and help to prevent smoke from spreading (which is often more hazardous than fire in the adjacent spaces). The proposed solutions - with the exception for steel profiles - can be considered satisfactory in terms of displacement values. Out of the tested solutions, the most effective was direct connection of the fire-resistant glass panels without the use of material profiles.
Przeprowadzona analiza jednoznacznie ukazała, że rozwiązania materiałowo-konstrukcyjne profili łączących szkło ochronne mogą mieć znaczący wpływ na szczelność ogniową. Typy połączeń, w których występowały niewielkie odkształcenia, wpływają na zachowanie stateczności przegrody i zabezpieczają przed rozprzestrzenianiem się dymu (który często jest groźniejszy niż pożar w sąsiednich pomieszczeniach). Zaproponowane rozwiązania - za wyjątkiem profili stalowych - można uznać za zadawalające pod kątem wartości przemieszczeń. W zestawieniu zdecydowanie najkorzystniej wypadła konstrukcja bezpośrednio łącząca tafle szkła ogniochronnego bez zastosowania profili materiałowych.

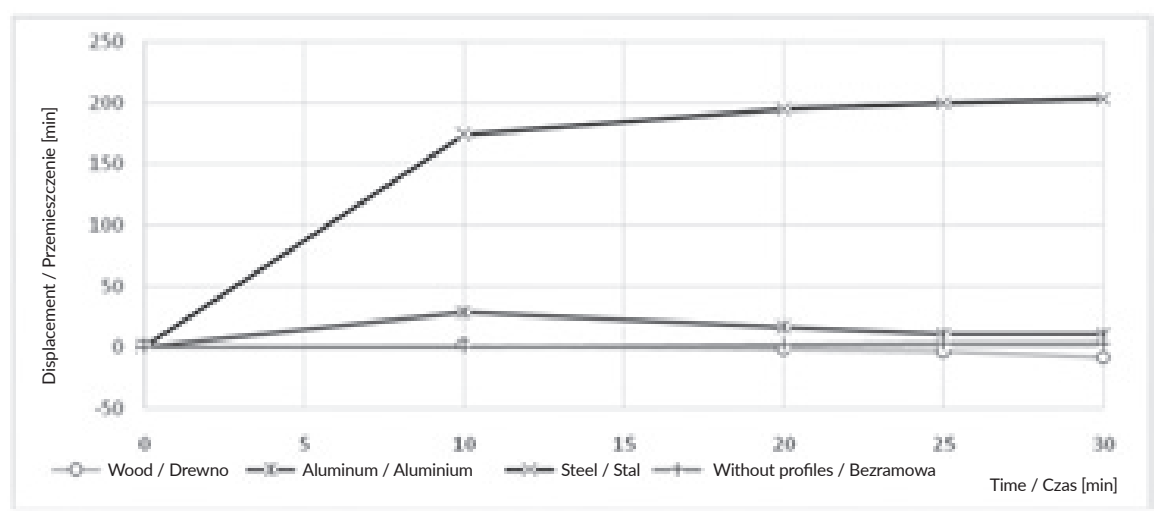

Rycina 8. Porównanie maksymalnych przemieszczeń na profilach wewnętrznych w zależności od ich konstrukcji

Figure 8. Comparison of maximum displacements on internal profiles depending on their constraction

Źródło: Opracowanie własne na podstawie wyników badań.

Source: Own elaboration based on test results.

\section{Literature / Literatura}

[1] Dane statystyczne KG PSP (www.kgpsp.gov.pl, dostęp 28.06.2019)

[2] Mickiewicz E., Szklane ściany działowe w biurach, „Świat Szkła” 2010, 5, 36-39.

[3] Laskowska Z., Kosiorek M., Bezpieczeństwo pożarowe ścian działowych przeszklonych: badania i rozwiązania, „Świat Szkła” 2007, 108 (5), 46-54.

[4] Laskowska Z., Borowy A., Rozszerzone zastosowanie wyników badań odporności ogniowej ścian działowych przeszklonych wg PN-EN 15254-4, „Materiały Budowlane" 2012, 7(479), 62-64.

[5] Sędłak B., Sulik P., Odporność ogniowa pionowych elementów przeszklonych, „Szkło i Ceramika” 2015, 5, 8-10.

[6] Sulik P., Sędłak B., Odporność ogniowa pionowych przegród przeszklonych. Część 2, Świat szkła, Nr 9, 2015, 31-35.

[7] Sulik P., Sędłak B., Ochrona przeciwpożarowa w przegrodach wewnętrznych, „Izolacje” 2015, 9, 30-34.

[8] Sulik P., Sędłak B., Wybrane aspekty oceny odporności ogniowej przeszklonych elementów oddzielenia przeciwpożarowego, „Journal of Civil Engineering, Environment and Architecture" 2017, 34(64), 17-29, https://doi.org/10.7862/rb.2017.100.
[9] Kinowski J., Sędłak B., Sulik P., Izolacyjność ogniowa aluminiowo szklanych ścian osłonowych w zależności od sposobu wypełnienia profili szkieletu konstrukcyjnego, „Izolacje” 2015, 20(2), 48-53.

[10] Sulik P., Sędłak B. Odporność ogniowa pionowych przegród przeszklonych. Część 1, „Świat Szkła”, 2015, nr 7-8, 37-43.

[11] PN-EN 13501-2+A1:2010 Klasyfikacja ogniowa wyrobów budowlanych i elementów budynków - Część 2: Klasyfikacja na podstawie badań odporności ogniowej, z wyłączeniem instalacji wentylacyjnych.

[12] PN-EN 1364-1:2015 Badania odporności ogniowej elementów nienośnych - Część 1: Ściany.

[13] Kinowski J., Sulik P., Sędłak B., Badania i klasyfikacja systemów pionowych przegród przeszklonych o określonej klasie odporności ogniowej, BiTP Vol. 42, Issue 2, 2016, 135-140.

[14] Raport z badań ogniowych witryny bezramowej nr 01/BZ/10/2018.

[15] PN-EN 1363-1:2012 Badania odporności ogniowej - Część 1: Wymagania ogólne.

[16] Raportyzbadańogniowych witrynywkonstrukcjistalowejnr02/Z/08/2013, aluminiowej nr 02/BZ/12/2012, drewnianej nr 01/BZ/09/2015. 
KONRAD PODAWCA, PH.D. - lecturer at the Faculty of Civil and Environmental Engineering at the Warsaw University of Life Sciences.

MAREK PRZYWÓZKI, M.SC. ENG. - civil engineer, an employee of POLFLAM Sp. z o.o
DR INŻ. KONRAD PODAWCA - adiunkt w Katedrze Inżynierii Budowlanej, Wydziału Budownictwa i Inżynierii Środowiska, Szkoły Głównej Gospodarstwa Wiejskiego w Warszawie

MGR INŻ. MAREK PRZYWÓZKI - inż. budownictwa, pracownik firmy POLFLAM Sp. z o.o. 